\title{
チベットの地質・古生物学上の最近の進歩
}

\author{
小 林 貞 一 \\ Recent Advancements in Geology and \\ Palaeontology of Tibet \\ Teiichi KoBayashI \\ はしがき
}

秘境と称せられていた西蔵の地質・古生物学的調査研究は近年長足の進歩を遂げ つつある。ここには下記の諸題目について述べる。

1. 西蔵南縁帯の層序

2. 西藏南縁帯とヒマラヤ西部との層序の比較

3. チベット高原の化石研究

4. チベット地質解明への雑賛と秋吉・佐川褶曲山脈の大陸への追跡

\section{I. 西蔵南縁带の啳序}

ヒマラヤの北坡，すなわち西藏南縁帯の層序論 は前世紀末 WHITE, C. と WREBENBURG, F. とが岡巴附近で侏羅紀菊石と白亜紀二枚貝を採取 したのに始まる。続いて HAYDEN, H. H. は今 世紀の初めに印度から北上して拉薩に至る間に石 炭系から第三系までの地層の存在することを予察 した。後に DOUville, H. (1916) はHの白亜一 第三系とする崗巴系の化石を，また AREKELL, J . A. (1953) は侏羅紀菊石を研究した。最近に至っ てこの地带に於ける中国人の踏查と研究は著しく 活発になった。先ゔ西蔵工作隊が 1951-53 年に日 喀則で三畳紀後期の化石を発見し，また珠峰北坡 で二㽝紀腕足貝を大量に採集した。その後 195660，1960-61，1963，1964，1966-68と調查が綝返 されて, ヒマラヤの山稜からブラマプトラ河の上 流の雅魯蔵布江（R. Tsangpo）との間，そして 東西では東径 $85^{\circ} 10^{\prime}-89^{\circ} 00^{\prime}$ の間に於いて古第三 系以下奥陶系までの精細な層序を化石を以って実 証し，その下に寒奥両系の地層の続いていること も確かめた。それに続いて1975年にはエベレスト 山，すなわち Mount Jolmo Lungma の北坡も
探査された。

これら一連の最近の調查研究の結果は

1. 珠穆朗瑪峰 (略 : 珠峰)地区科学考察報告, 1966-68 の地質, 1974, 古生物 5 分第 1 分冊, 1975, 第 $2 \cdot 3$ 分冊, 1976.

2. 珠穆朗瑪峰科学考察 (1977), 地質, 1979. として出版された。なお前者の続巻として，第四 紀地質・現代水川興地貌・生物興高山生理なども 出版されている。

この地区で最古の含化石層は甲村層群で, 主に 石英岩からなり, その下部で Ordosoceras-Manchuroceras 帯とDideroceras-Michelinoceras 帯 とが認められ，上部中に Sinoceras, Michelinoceras 等を産することが判明した。その上に無化 石の紅山頭頁岩が, そして更に上に単筆石や $M i$ chelinoceras, Triplophyllum などを産する中下 部志留部系の石器坡層群がある。

泥盈系は志留系とは断層で境しているが, 泥盈 系中 - 下部の涼泉組中に Neomonograptus himalayensis 帯, Nowakia acuaria 帯, Guerichina xizangensis 帯の 3 者が識別されている。 上部の波曲石英砂岩は無化石で, Muth 珪岩に対 比されている。石炭系は泥盈系を整合に被い，整 
第 1 表 珠楮朗瑪地区南部の層序の概要

\begin{tabular}{|c|c|c|c|c|}
\hline 代 & 地 層 & 層厚 & 主 要 岩 石 & 化 \\
\hline 古第三紀 & $\begin{array}{l}\text { 遮 普 惹 組 } \\
\text { 宗 浦 群 }\end{array}$ & $\begin{array}{r}1285 \\
383\end{array}$ & $\begin{array}{l}\text { 石灰岩 /頁岩 } \\
\text { 石灰岩 } / \text { 頁岩 }\end{array}$ & $\begin{array}{l}\text { Nummulites, Orbitolites, Assilina } \\
\text { Campanite, Bernaya }\end{array}$ \\
\hline 白 亜 紀 & 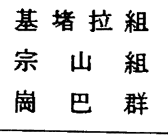 & $\begin{array}{r}188 \\
278 \\
1187\end{array}$ & $\begin{array}{l}\text { 石英砂岩 } \\
\text { 石灰岩・頁岩 } \\
\text { 頁岩（泥灰岩・頁岩） }\end{array}$ & $\begin{array}{l}\text { Vrolebris, Xertoberis } \\
\text { Orbitoides, Globotruncata } \\
\text { Hemiaster, Mortoniceras, Neohoploceras }\end{array}$ \\
\hline 侏 羅 紀 & $\begin{array}{l}\text { 古 錯 組 } \\
\text { 門卡墩 組 } \\
\text { 和々雄拉群 }\end{array}$ & $\begin{array}{r}710 \\
360 \\
2060\end{array}$ & $\begin{array}{l}\text { 頁岩（砂梊頁岩） } \\
\text { 石灰岩（砂岩・頁岩） }\end{array}$ & $\begin{array}{l}\text { Hoplophylloceras, Virgatosphinctes } \\
\text { Macrocephalites, Schlotheimia }\end{array}$ \\
\hline 三 畳 紀 & $\begin{array}{l}\text { 德 日 栄 組 } \\
\text { 曲竜共巴組 } \\
\pm \quad \text { 隆 群 }\end{array}$ & $\begin{array}{l}591 \\
465 \\
640\end{array}$ & $\begin{array}{l}\text { 石英砂岩（炭啠頁岩） } \\
\text { 頁岩・砂質頁岩互層 } \\
\text { 石灰岩（砂質頁岩） }\end{array}$ & $\begin{array}{l}\text { Myophoria, Paloeocardita } \\
\text { Pinacoceras, Cyrtopleurites } \\
\text { Daonella, Otoceras, Claraia }\end{array}$ \\
\hline 二 畳 & 色 竜 群 & 281 & 石灰岩・泥灰岩 & Marginifera, Waagenophyllum \\
\hline 石 崖 紀 & 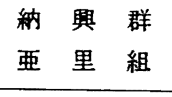 & $\begin{array}{r}1888 \\
126\end{array}$ & $\begin{array}{l}\text { 頁岩（石英砂岩） } \\
\text { 頁岩（泥灰岩） }\end{array}$ & $\begin{array}{l}\text { Syringothyris, Conularia } \\
\text { Imitoceras, Tylothyris }\end{array}$ \\
\hline 泥 盈 紀 & $\begin{array}{ll}\text { 波 } & \text { 曲 } \text { 群 } \\
\text { 涼 } & \text { 泉 }\end{array}$ & $\begin{array}{r}256 \\
40\end{array}$ & $\begin{array}{l}\text { 石英砂岩 } \\
\text { 頁岩 }\end{array}$ & Nowakia, Neomonograptus \\
\hline 志 留 紀 & 石器 坡 群 & 136 & 石灭岩／砂岩・頁岩 & Monograptus, Favosites \\
\hline 奥陶紀 & $\begin{array}{l}\text { 紅 山頭 組 } \\
\text { 甲 村 群 }\end{array}$ & $\begin{array}{r}70 \\
823\end{array}$ & $\begin{array}{l}\text { 頁岩（細砂岩） } \\
\text { 石灰岩（杼砂岩） }\end{array}$ & Sinoceras/Manchuroceras \\
\hline 寒 奥 紀 & 肉切村群 & $40-160$ & 石灰岩／石英片岩 & \\
\hline 先 寒 紀 & 珠楾郎馾群 & & & \\
\hline
\end{tabular}

波線：非整合, 点線：断層接触, 斜線：上下関俰, 括弧：随伴岩石

合的に二畳系に被われている。石炭系は主に砂 岩・頁岩からなり,その下底部の亜里組はImitoceras を, その主部の厚い納興層群はSyringothyris その他の腕足介, Conularia, 二枚貝等を 産する。二畳系は砂岩・頁岩・石英岩等からな り, 腕足貝・珊瑚・蘇虫等からなる豊かなフォー ナを蔵していて，陽新フォーナに比較されてい る。楽平統は欠けているようである。

この堆積間隙を置いて三畳系は Otoceras, Ophiceras, Gyronites を含む Skytian に始ま り,ノーリック階まで多くの菊石帯や二枚貝帯が 認められている。ノーリック階中には Himalayasaurus tibetensis と称する魚竜が発見されてい る。この地帯の北部では Monotis salinaria や有
孔虫を産する 2,500 メートルの厚層があり，砂岩・ 頁岩層の間に喽岩や石灰岩を挾み，含放散虫珪質 岩や塩基性火山岩をも伴っている。

侏羅系はこの地帯の南部に発達していて, 菊石 で Hettangian, Sinemurian, Toarcian, Bajocian は認められるが, Pliensbachian と Bathonian とは詳かでない。Callovian 以上の上部侏羅系に も種々の菊石を産するが，Oxfordianの菊石は見 出されていない。菊石のみならず辫鰓類・六射珊 瑚その他の化石もあり, 日本の鳥巣石灰岩のよう に定日県では侏羅紀後期の層孔虫や Spongiomorpha, chaetetids を含む石灰岩があるが種属と しては趣を異にしている。

白亜系はこの地区の南北で層相を異にし, 南部 
は皆海成で化石が豊富であるのに反して，北部で は化石が甚だ少く，厚層で陸成相が発達してい る。海成白亜系は崗巴地区では下部の崗巴層群の 厚さは 1,187 メートルで, 頁岩を主とし, 下部に 石灰岩があり，菊石その他の化石で，その時代は Barremian から Santonian までとされている。 その上の宗山層群中の石灰岩は有孔虫や二枚貝を 多産し, その最頂部の砂岩からなる基堵拉層も含 めて, Campanian-Maestrichtian である。北部 では頁岩・砂岩に石灰岩を挾み，菊石・箭石・有 孔虫を含んでいる。特に日喀則・昂仁一帯では砂 岩が発達して礫岩を挾み石灰岩は極めて稀で, Orbitorina やサンゴを産出するが，また被子植 物や淡水棲二枚貝を含む地層もあって, 新白亜紀 の様相を呈している。

南北間の層相の相異は古第三采に於いて更に著 しい。南部では石灰岩が発達し, 有孔虫・介形類・ 巻貝・二枚貝・オーム貝類・サンゴ・海藻等を蔵 している。定日地区では下位の宗浦層群と上位 の遮普惹層からなり, 前者は Danian-Lutetian で後者は Lutetian 上部-Ledian である。北部の 第三系には海成相は見当らない。陸成と見做され る紫紅色粗䂶屑岩の地層で 700 メートル以上の厚 さを有し化石は発見されない。

特筆すべき新発見として, 珠峰北側の定日県怕 卓区曲布で Glossopteris 3 種を含む 羊歯植物群 が発見されて古植物地理学上で注目を惹いてい る。また曲布の三畳系下底部の白雲岩中からへリ コプリオン科の Sinohelicoprion gomolangma, sp.nov. が発見された。三冨紀の蘇虫類は世界的 に甚だ稀であるが，琹拉木県士隆から Paralioclema 3 新種が記載されている。先きに述べた魚 竜は土隆・曲布等のノーリック層中に埋蔵してい るのであるが, カーニックからも多少見出されて いる。

奥陶紀の甲村層群下には結晶質石灰岩, 更に下 には石英片岩を主とする地層があり, 肉切村層群 に一括して, 寒武奥陶系とされているが, 恐らく 震且系に及ぶであろう。珠峰地区には種々の深成 岩・変成岩・混成岩がある。K-Ar 法, U-Pb 法, $\mathrm{Rb} \cdot \mathrm{Sr}$ 法等に依る年齢測定結果変成岩類に 2 期が 識別される。古い方は先寒武晚期で640-660my.,
新しい方は第三紀で 10-20my. で，後者の 変成 はヒマラヤ造山に伴う花崗岩墏の侵入と関係があ る。

\section{II. 西藏南緑带とヒマラヤ西部と の虽序の比較}

ヒマラヤ山系は北からチベット帯, テチスヒマ ラヤ帯および準ヒマラヤ帯の3 地質区に分けら れ，西蔵南縁帯は Tethys Himalayan zone の 中部北側に位している。従来ヒマラヤ山脈の古生 層についてよく判っていたのは錫金 (Sikkim) 以 西で, Spiti，Kumaon が特に重要である。この 地方に Haimanta と呼ぶ千メートル以上の厚層 があり，その上部は主に珪岩・頁岩・板岩からな り，白雲岩の薄層を挾んでいる Parahio 統で, その下位に Redlichia 頁岩がある。更に上方に 中部寒武紀の化石を多産する。同系の中下部は恐 らく先寒武紀で, 震且紀のものであろう。多分肉 切村層群は八イマンタ系に近い地層であろう。

奥陶・志留両系もまたスピチによく発達してい る。その基底部の頁岩・珪岩を除くと大部分が石 灰岩ではあるが，奥陶系では腕足貝と三萧虫が， 志留系では珊瑚が豊富で, 両系共頭足類は多産し ない。この地方では稀に泥盈紀化石が石灰岩中に 含まれているのみで, 泥盈紀腕足貝や珊瑚などは Kashmir の北西部 Chitral に多産する。スピテ ィの古生層下段は無化石白色の Muth 珪岩で終 っていて, 波曲層群がこれと対比される。その上 に石炭紀の Kanawar 系が重なり, 下位の Lipak 統は石灰岩・頁岩からなり, 納興層群の如く $S y$. ringothyris を産する。上位の Po 統は Fenestella 頁岩で, その下部を占める Thabo 階は植物化石 を産する。二畳紀の Kuling 層群の基底礫岩は Po 統および更に古い地層を不整合に被い，下部 は石灰質砂岩, 上部は Productus 頁岩で, 共に 腕足貝その他の化石を産する。

三畳系はその上に重なる厚さ約 1,300 メートル の Lilang 層群で, 黒色石灰岩に頁岩を挾み, 全 体が化石に富んだ海成層で，その上頂部約 600 メ ートルの Megalodon 石灰岩, あるいはKioto 石灭岩はレトリアスである。従ってその上段は聶 々雄拉層の下部に相当する。スピティ地方ではこ 
れを被うている Spiti Shales があり，Oxfordian から Necomian 下部に達している。その上に Flysch 相の Giumal 砂岩が来る。その最上部は Albian に及んでいる。次いで Chikkim 石灰岩 頁岩層が重なり, 上方へと無化石のフリッシュ相 に移化し，その上部では塩基性熔岩を伴ってい る。この時期にはテチスヒマラヤ帯は処々で状況 を異にし, 珠峰地区でも南北間で層相が変化し, 北部には陸成相が出現する。このようにこの地方 では白亜系上部に，また珠峰地区では三畳系上部 に火山岩が認められているが, 少くとも寒武紀以 上の本帯の層序中に火山源の物質は僅かしか含ま れていない。

テチスに属するこの地帯では白亜中後期から造 山運動が展開し, 上部始新期には南側では海成 相, 北側では非海成相と分化し, 中新中期の激動 時階に海は消滅して，ヒマラヤ山脈南麓に非海成 の Siwalik 層群を堆積した。そして鮮新末期・ 更新前期の運動で遂に準ヒマラヤ帯が形成され た。

\section{III. チベット高原の化石研究}

西蔵から青海にかけての高原地域の地質調查が 最近如何に急速に進歩しつつあるかは, 中国古生 物学会 第十二屆学術年会及第三届全国会員代表 大会 学術論文摘要集 1979年 4 月を見ると, ま ことに警くべきものがある。蘇州で開催されたこ の学会注1)では特に青蔵高原の古生物と題するシ ンポジュームがあり,26論文が提出され，その他に も $1 \cdot 2$ の関係論文が他のセクションに出てい る。勿論予報的なものではあるが, 多数の専門家 に依って奥陶紀以降の各地質時代の動植物化石の 研究が着々と進められているのであるから，その 本報が公表される日は遠くあるまい。ここではそ の予告を概観してみる。

珠峰西方の焣拉木で奥陶紀化石の発見されたこ とは既に述べたが， Maclurites がヒマラヤ山脈 東端部の察隅地区でも見出された。チベット南部 の辣拉木と中部の班-戈では志留紀前期の床板珊瑚 や四射珊瑚を産する。泥盈紀床板珊瑚は高原東南 部の芒康, 西南境の普蘭等で, また中上部泥盈紀 の四射珊瑚は高原東部の昌都や阿里で見出されて
いる。二畳石炭紀床板珊瑚は芒康を過ぎる東部に 広く分布している。西蔵の古生代腕足貝は 6 新属 を含む57属69種に及び，そのうちには西境の日土 県産の志留紀 Hindella 1 新種もある。

石炭紀蘚虫類は昌都・珠峰・南崑崙山等の諸地 区で採集されていて，11属18 種が識別されてい る。昌都一帯に分布する二畳紀蘚虫類は25属75種 に及んでいる。この地方にはまた石炭紀前期の四 射珊瑚を多産し，華南特に貴州のフォーナに近 い。同紀後期のものは珠峰北側から知られている。 二畳紀珊瑚は雅魯蔵布江の南北で趣を異にし，北 側では暖水型の造礁珊瑚が発展している。青海天 唆県布哈河流域では18新種を含む34種の二畳紀二 枚貝が採集されている。

西蔵の紡鍾虫は11科42属 115 種を容していて, その27種は新種である。石炭紀のものは芒康・左 貢・昌都等高原東部に分布し, 前期の Eostaffella 帯, 中期の Profusulinella 帯と FusulinellaFusiella 帯, 後期の Triticites 帯とPseudoschwagerina 帯に属し, 二畳紀前期のものは Misellina 帯と Cancellina 帯, 中期のものは Neoschwagerina 帯, 後期のものは Palaeofusulina 帯に帰せられる。西蔵中部の奇林湖四近ではNeoschwagerina, Kahlerina, Verbeekina, Schwagerina 等からなる茅ロフォーナ Neoschwager ina 帯) が広く分布している。

中生代の化石 の中では蔵東の 昌都・阿里・安 多・改則の 4 地区を主とする25産地のうち三畳系 と侏羅系は各々 11 個所, 白亜系は 3 個所から蒐集 された多量の腕足貝があり，17科,52属,86種に達 している。そのうちに 2 新亜科, 9 新属, 45 新種が 含まれている。西蔵の六射珊瑚もまた豊富で，力 ーニックーーノーリック下部のものは昌都附近と ヒマラヤ北側に分布している。ジュラ紀前期の珊 瑚はヒマラヤ北側の吉隆から知られ，ジュラ紀中 後期のものは広く東西に分布している。旧白亜紀 の珊瑚は西蔵西南部にあり，ジュラ後期と白亜前 期の色彩を帯びている。白亜紀後期のものは雅魯 蔵布江沿岸からヒマラヤ山脈にかけて分布し，第 三紀の珊瑚に近い様相を呈している。

西蔵の三畳紀菊石類27属37種中には

1. 岡底斯山南坡の Smithian 菊石 8 属 8 種 
第 2 表 珠稳朗瑪漆地区の化石群

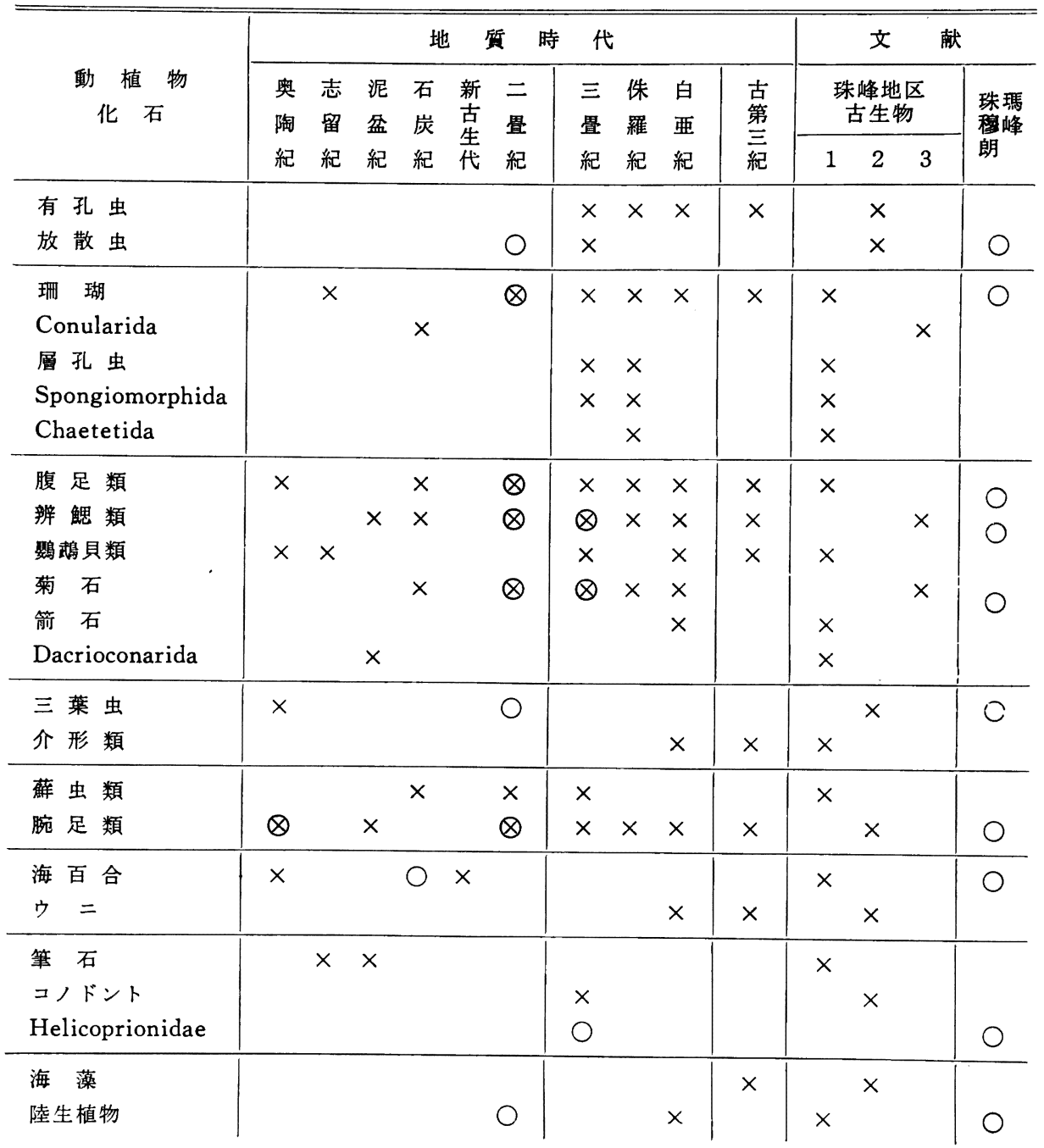

2. 藏北双湖の南から Anisian 菊石 9 属13種

3. 西蔵東南隅の察雅県の Norian 菊石10属16 種

がある。更に拉薩西北方 $67 \mathrm{~km}$ 堆竜徳慶県で, 3 新 種を含む 21 種からなるアニシック後期の Paraceratites trinodus フォーナも発見されている。

ヒマラヤのライアスは菊石17属18種中 1 新属 2 新種を含み, Hettangian 初期, Sinemurian 初 期, Pliensbachian 等の 3 菊石群が区別されてい る。
中生代各紀の箭石もまたチベットから発見され ている。そのうちには三畳紀後期の諸属, 中部ジ ユラ紀 Bajocian のもの, ジュラ・白亜両紀過渡 期のものなどが識別されている。

西蔵中部の班戈の白亜系は Aptianのネリネア の諸種属を蔵している。拉薩地区の下部白亜系は Aptian, Albian の十脚類数種を産している。白 亜紀海成層はまた種々の Orbitolina を多産し, そのうちに新属 Neorbitolinopsis と 2 新重属 Orbitolina (Eorbitolina, Columnorbitolina) が 
ある。

西藏東部の昌都・芒康・察隅地区や西苌崙東端 部の喀拉米阔山等の奥陶・石炭・二畳・三畳・侏 羅・古第三系は Dasycladaceae, Codiaceae, Solenoporaceae, Melobeciae, Gymnocodiaceae, Porostroma 等に属する38属54種の藻類乃至所属 不詳のものを産する。それらのうちに 1 新属12新 種がある。この藻類化石中にはテチスのものや日 本のものと類縁が認められている。

陸生植物では昌都地区で紡錘虫・腕足貝との関 係で上部二畳系下段に置かれている当䩗層中に 5 新種を含む36種の植物化石を産するが，そのうち

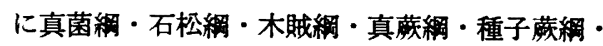
銀杏網等がある。これは華北や華南のカタイシア 植物群と比較され, 多湿な熱帯乃至亜熱帯のフロ ーラと見做されている。西蔵中北部の双湖地区で 含 Palaeofusulina 層と含 Claraia 層との間か ら17種の植物化石が発見された。その時代は二畳 紀終末ないし三撂紀初頭で, 温暖多湿の熱帯乃至 亜熱帯の植物相を呈している。

西蔵東部に三畳紀後期の 2 植物群があり, 若い 方の巴貢層産のものは Hongay や成羽のフロー ラに対比されノーリックで, 古い方の甲不拉層の ものはカーニックないしノーリック前期とされて いる。拉薩から東方へ怒江までの間の海成上部侏 羅系上の夾炭多尼層から採集された植物群はウキ ールデン型で, 日本の領石フローラに比較され, 沿海多湿高温の気候下のものと考えられている。

中国科学院青蔵高原綜合科学考察隊古脊椎動物 組は拉看・昌都等でジュラ紀前期・中後期および 新白亜紀の多量の化石を採集した。そのうちには

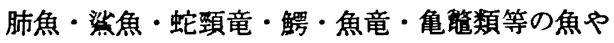
爬虫類が含まれている。1978年に青海の西窂盈地 で採集された中新前期の小型哺乳動物群には10属 13種が識別され，その時代は Aquitanian-Burdigarian に当る。

青海高原の丁青地区では古第三紀の淡水棲巻貝 が，また札達地区では新第三紀の淡水棲巻貝が見 出されている。更に青蔵公路上の臮崙山口と唐古 拉山口との間の 4 個所の掘毁から鮮新更新期ない し更新前中期の淡水棲或いは湖棲の 2 科 10 属 40 余 種の介形虫が採取されているが, 温暖低地のフォ
一ナで, 高寒の現在位㯰はその後の隆起による。

\section{IV. チベット地質解明への雑筫と秋吉} 佐川裨曲山眽の大陸への追跡

四半世紀程前拙著「東亜地質」のなかで私は 「タリム盈地からヒマラヤ山脈まで」の 1 章でチ ベット地質を素描したことがあった。当時はLE. UCHS, K. のアジアの地質 1 巻 2 部 (1937) はア ジア中部の地質を知るための好著であった。その うちに崑崙山系から西蔵高原を経てヒマラヤ山系 に至る間の地兵がかなり詳しく述べてあった。李 四光の名著 Geology of China，1939ではシナ本 部の地兵は非常によくまとめられているが，新疆 や西蔵の地質は看却されていた。その地域層序の 章には西康東部は含まれているが，東径百度以西 は除外されていた。

1945の黄汲清著 On Major Tectonic Forms of China 中央地質調査所専報甲種20号は英文て はあったが絶版で，永い間広く読まれなかった。 1952年にソ連版が出て1957年に至って原文を補足 し中国主要地質構造単位と題した中国版が出たの で，私は胡忠恒の協力を得て本誌67巻（1958）に これを紹介した。この論文は中国全土に亘って構 造区分とその発達史を論じた画期的な名著であ る。

1949年には中華人民共和国が成立して，1951年 には既に中国科学院の西蔵地質調査が開始された ことは既に述べた。1955年には劉鴻允の中国古 地理図が出版され，続いて出た中国区域地層表 $(1956,58)$ には喀喇息崙山, 西蔵中部・喜馬拉雅山 及び雅魯蔵布江中游区等の層序が表示された。ま た 徐近之編青康蔵高原及昆連地区・西文文献 462 頁, 科学出版社, 1958 には地質・地震・岩石・ 化石・地形・隶河等が40頁を占めている。

全国地質会議学術報告量編（1964）になると西 蔵区の項にスピティの Haimanta 層群のみなら ず，カシミルの寒武系も要約され，西蔵西部の項 にヒマラヤやカラコルムの奥陶系を摘記してい る。志留系に就いても同様で，泥盈系以上の諸系 に於いては西蔵に於ける化石の新発見や層序観察 など中国地質家の成果が随所に載っている。 上記の珠峰地区の報告はすなわち最近30年間の 


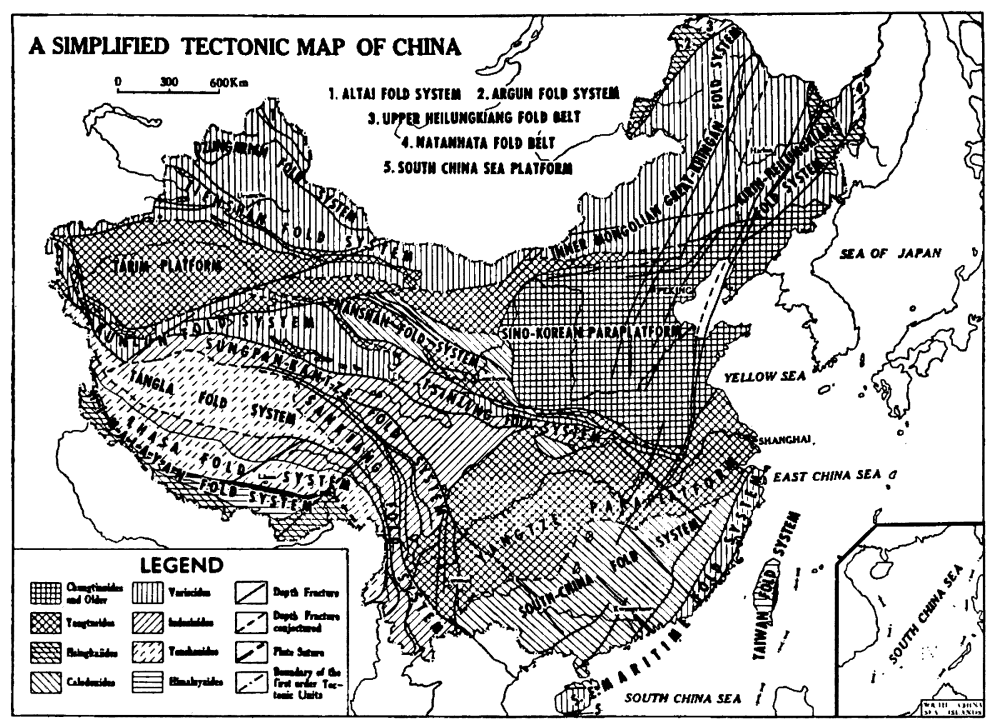

第 1 図中国地質構造図（黄汲清，1978より）

この地区の地質学古生物学的諸研究を集大成した 成果であり，昨年の中国古生物学の青蔵高原的古 生物シンポジュームはその分野に於ける行進曲と もいうべきもので，その本報が出版された暁には 秘境と呼ばれたこの高原の地質は面目を一新する であろう。しかし，この豊富な化石資料の産地か ら推察すると, その大半は高原の東部と中南部の ものであって, 残余の一半が分明するまでには更 に若干の時を要するであろう。

Sven HEDIN はチベット高原の地理・地質解 明の先駆者で, 崑崙・青海・西康・ヒマラヤ北坡 等に対しては前世紀後半に諸外国人の挺身的踏査 が行われた。平均高度 $4,000 \sim 5,000$ メトルのこ の高原は北はコンロン，南はヒマラヤに抱れた地 塊のように見えるが，高原上には200〜 400メート ルの多数の山脈が東西に走り，西方では16，東で は36が数えられている。換言すれば山列は西方パ ミールに向って収斂し, 東には放散し西康に於て 急に屈曲南下している。

黄汲清はその前著に於いて既に蔵北が古生代後 期, 蔵南が中生代の裮曲山列であると説いている。 最近の黄らの所説注2)によると 南山はカレドニア 造山，鼠崙はバリスカン造山，秦岺は印支造山が 主要地殼変動で，これら北部の褶曲山脈は金沙
江一紅河の深部破砕帯によって南部から隔てられ ている。南部には北から三江，Tangla, Lhasaの 3 褶曲山脈があり，第 1 と第 3 は印支造山，両者 間の拉薩山脈は燕山造山の産物である。そして Indus, Tsang 両河の南を走るヒマラヤは西の Sulaiman, 東の Arakan Yoma と共にヒマラヤ 造山によりインド剛塊を縁取る褶曲山脈で，西蔵 高原の中古生代諸山脈の外にあるという（第 1 図 参照)。

珠峰地区科学考察報告，地質（1974）中で同地 区の地質構造とヒマラヤ及び青蔵高原との関係に 就いての常承法と鄭錫瀾の所見は黄らといささか 異っている。すなわち両氏によると北から阿爾金 山 (Altyntag), 崑崙山, 唐古拉山（Tongola）, 崗底斯 (Kangtiszu)，喜馬拉雅山を頂く 5 プレー トを認め，それぞれを順に柴達木 (Tsaidam), 姜 塘 (Qiangtang), 蔵北, 蔵南, 印度のプレートと 呼び地質時代と共に北のプレートの衝上，すなわ ち南のプレートの突込みを生じて, 山脈を形成 し, 地款運動が次々に南進する。従って, 上記 5 山脈の花崗岩の年齢は北に古く阿爾金山では344554 my., 崑崙山では 240-280my., 唐古拉山では 107-210my., 崗底斯山では30-70my., 喜馬拉雅山 では10-20my. であると（第 2 図参照)。 

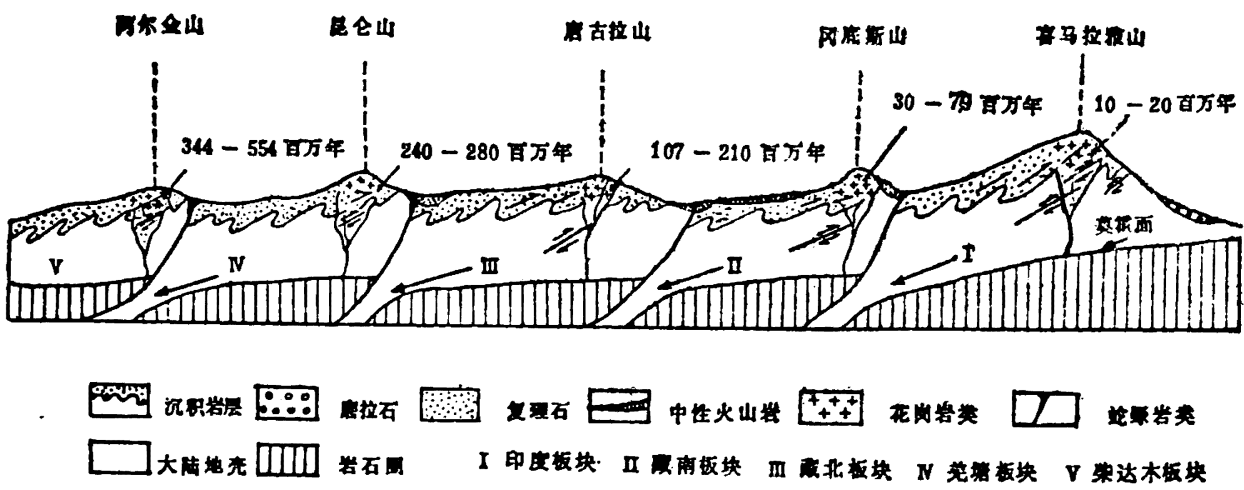

第 2 図阿爾金山・喜馬拉雅山間の地質構造概念図（常承法 鄭錫㳊阑，1974 より)

現在進行中の青蔵高原古生物の研究はまず山脈 別の層序を確立し，一方では古地理図を修正補足 し，他方では構造発達史上の所説を取捨選択する であろう。しかし高所から見るならば両説共ども 造山運動の北から南への波及に於いて一致してい るのである。私は且つて大局から見て北半球に於 いては山化は核塊から赤道方向へ南進している が, これを環太平洋区域の構造発達史から推察す れば，山化は太平洋海盈へと求心的に進行してい る。そして, アジア大陸の要素が崩壊しつつある 南方大陸の要素とインドで接触してからは山化は 只管太平洋海盈へと求心的発展に向っていること
を示唆した注3)。青蔵高原の造構史の 所説はこれ と合致し,この高原の古生物学的研究がこれを実 証せんとしている。

1943年私は秋吉造山帯の西方延長がパミールに 達するであろうことに注目を喚起した注4。1952 年には秋吉带南西翼が印度支那, 今日のベトナム 北部に達しているであろう事を指摘した注5)。そ して最近の APRSA project の結果日本の中生 代褶曲山脈が東南アジアを経由して西康へと北上 することがいよいよ確実になって来た注6)。この 中生代褶曲山脈は西康で西折して藏南を横断して いるのである。

注 1)この会については，高井冬二：わが訪中記. 化石，29号123-129頁 昭和54年を参照。

注 2) Group of Tectonic, Institute of Geology and Mineral Resources, Academy of Geological Sciences (1977), An Outline of the Tectonic Characteristics of China, 24 pp. Peking, China.

注 3）佐川輪迥 (英文)，1941，534-536頁; 日本地方地質誌総論 (朝倉書店), 297-299頁.

注 4）中央严細严の古地理変要と地質構造発達史. 地理学, 11 巻 4 号, 335-449頁.

注 5) On the Southwestern Wing of the Akiyoshi Orogenic Zone in Indochina and South China and its Tectonic Relationship with the Other Wing in Japan. JJGG, v. 22, pp. 27-37.

注 6) KoBAYASHi, T. (1980), Notes on the Mesozoic Histor y of Thailand and Adjacent Territories. Geology and Palaeontology of Southeast Asia vol. 21, pp. 27-26.

(1980年10月11日受理) 